\title{
STUDY OF RHIZOBIA IMPACT ON NUTRITIONAL ELEMENT CONCENTRATION IN LEGUMES
}

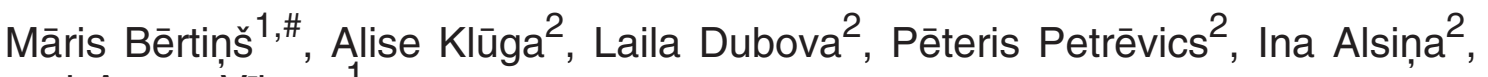 \\ and Arturs Vīksna ${ }^{1}$ \\ ${ }^{1}$ Faculty of Chemistry, University of Latvia, 1 Jelgavas Str., Rīga, LV-1004, LATVIA \\ ${ }^{2}$ Institute of Soil and Plant Sciences, Latvia University of Life Sciences and Technology, 2 Lielā Str., Jelgava, LV-3001, LATVIA \\ \# Corresponding author, maris.bertins@lu.lv
}

Contributed by Ina Alsiṇa

\begin{abstract}
The concentration of nitrogen in the Earth's atmosphere is about $78 \%$, but most plants are not able to acquire it directly from the atmosphere. One of the most common ways for binding atmospheric nitrogen is the development of an efficient symbiotic system between legumes and rhizobia. The aim of this study was to compare how different legumes and rhizobia symbiosis systems affect the concentrations of nutrients and other elements in soya and faba beans. Seeds of plants were inoculated with a preparation of rhizobia just before sowing. Plant samples were collected at the flowering stage (vegetative parts) and during harvest (seeds). Samples were air-dried and analysed with inductively coupled plasma mass spectrometry (ICP-MS). Total nitrogen and carbon concentrations were determined with an elemental analyser (EA). The obtained results showed that inoculation of legume plants with rhizobia not only affected nitrogen uptake by plants but also uptake of other elements. Inoculation had an effect on mineral element uptake for both faba bean and soybean leaves, where a significant increase in $\mathrm{Mg}, P, K$, and Ca was observed. Treatment of legume plants with rhizobia caused a decrease of $P$ and $K$ concentrations in seeds, and there were changes in $\mathrm{Fe}$ and Mn concentrations.
\end{abstract}

Keywords: faba bean, soya, nitrogen fixing bacteria, macro-elements, micro-elements, ICP-MS.

\section{INTRODUCTION}

Legumes belong to the Leguminosae family, which is also called Fabaceae. The Leguminosae family includes more than 18000 species of herbaceous plants, climbers, and trees, of which only a few are used as a human food source. Legumes such as peas, beans, lentils, peanuts, lupines, and soybeans are used for human consumption. They are found on all continents and can grow under different climatic conditions. Legumes are one of the most important foods, and in combination with cereals can provide all of the amino acids necessary for human nutrition (Maphosa and Jideani, 2017). In addition to the valuable chemical composition of legumes, they also have an important property - symbiotic binding of atmospheric nitrogen (Dubova et al., 2018).

One of the most important factors for a good yield is the use of nitrogen fertilisers. Therefore, farmers use nitrogen fertilisers as much as possible. The disadvantage of this practice is that the fertilisers are relatively expensive and that their use in large quantities pollutes the environment. As a result, researchers are trying to find alternative methods that will increase yield quantity and quality, which are more environmentally friendly, and minimise costs for farmers (Chojnacka et al., 2020).

It is well known that due to the legume symbiotic relationship with rhizobia, legume yield can be improved. This is because of the ability of rhizobia to acquire nitrogen directly from the atmosphere (Poole et al., 2018). Fixed nitrogen is converted to ammonia, which can be used by plants as a natural fertiliser, therefore eliminating the need for additional fertilisers. The use of rhizobia also benefits the following crops because part of the accumulated nitrogen remains in the soil, in this way eliminating the need for chemical fertilisers (Šenberga et al., 2017).

The main reason why legumes are a very important crop in agriculture is their high concentration of proteins and amino acids, especially lysine. Legumes play an important role in 
developing countries (e.g., Africa, Asia, and South America). Legumes are called "the bread of the poor men" because of the observed inverse relation of legume consumption and income (Messina, 2016). Despite the available nitrogen levels in soil, legumes tend to produce as many seeds as possible. This is possible due to a decrease in protein concentration in the seed. To increase protein concentration in seeds, nitrogen sources like nitrogen fertilisers or seed inoculation with the appropriate strain of rhizobia must be applied (Minta and Tsige, 2014; Tena et al., 2016).

Legumes are also a source of essential mineral elements like calcium, phosphorus, potassium, magnesium, iron, and zinc. These nutrients play important roles in human physiology. For example, calcium is needed for bone health, copper is involved in enzyme activity and iron metabolism, iron is needed for haemoglobin synthesis, and zinc for antioxidative activity, protein synthesis, and plasma membrane stabilisation (Mogobe et al., 2015).

By applying the biological nitrogen fixation method using the rhizobia-legume symbiotic system, there is no need for application of mineral nitrogen fertilisers. The only changes in the elemental concentration of legumes, in this case, are due to physiological processes in legumes, in which some of the elements have a significant role. The aim of this study was to evaluate the effect of treatments with and without application of rhizobia on the concentrations of some nutritionally important elements $(\mathrm{Ca}, \mathrm{Cu}, \mathrm{Fe}, \mathrm{K}, \mathrm{Mg}, \mathrm{Mn}$, $\mathrm{Na}, \mathrm{P}$, and $\mathrm{Zn}$ ) in different parts of faba beans and soybeans.

\section{MATERIALS AND METHODS}

Field experiments were set up to determine the effect of rhizobia on the uptake of mineral elements in plants.

Experiments with faba beans were carried out at the Study and Research Farm "Pēterlauki", Latvia University of Life Sciences and Technologies. Faba bean Vicia faba var. minor cultivar 'Lielplatone' was used. The sowing rate was 45 seeds per $\mathrm{m}^{2}$. The size of each plot was $9 \times 2 \mathrm{~m}$. The field experiment consisted of four replicates. The rhizobia used in the experiments were obtained from the collection of the Institute of Soil and Plant Sciences, Latvia University of Life Sciences and Technologies. Seeds were inoculated with the rhizobia before sowing. Unsterilised seeds were soaked for $30 \mathrm{~min}$ in a suspension of bacteria with a concentration of microorganisms $10^{6}$ cells per $1 \mathrm{ml}$. The seeds were air-dried before sowing.

Experiments with soybean cultivar 'Laulema' were conducted at the farm "Ezermeli-3", Durbe Municipality, Latvia. The sowing rate was 65 seeds per $\mathrm{m}^{2}$. The experiment was organised in four replicates. Seeds of soya were inoculated with a dry commercial preparation of rhizobia (BASF) just before sowing and control seeds were left without inoculation.
Due to the absence of indigenous rhizobia in the soils of Latvia, no nodules were observed on the roots of control soya plants during plant growth. Soya plants developed from treated seeds had nodules on their roots, which was evidence of the development of a symbiotic system between nitrogen-fixing bacteria and plants. However, all of the beans in all variants had nodules on roots. The intensity of nodulation varied. Control variants had fewer nodules and they were smaller.

Plants were analysed during the flowering stage (stems and leaves) and after harvest (seeds). Samples were air-dried and analysed with inductively coupled plasma mass spectrometry (ICP-MS). Microwave-assisted acid digestion using trace grade nitric acid and hydrogen peroxide was applied for sample preparation. Total nitrogen and carbon concentration were determined with an EuroVector EA3000 elemental analyser.

For the determination of element concentrations in the legume samples, an Inductively Coupled Plasma Mass Spectrometer (ICP-MS, Agilent 8900 ICP-QQQ) equipped with a MicroMist nebuliser was applied for the determination of the following elements - $\mathrm{Ca}, \mathrm{Cu}, \mathrm{Fe}, \mathrm{K}, \mathrm{Mg}, \mathrm{Mn}, \mathrm{Na}, \mathrm{P}$, and $\mathrm{Zn}$. The instrumental parameters of the ICP-MS were set as follows: RF power $-1.550 \mathrm{~W}$, auxiliary gas flow $0.90 \mathrm{ml} \cdot \mathrm{min}^{-1}$, plasma gas flow $-15.01 \cdot \mathrm{min}^{-1}$, He cell gas flow $-5.0 \mathrm{ml} \cdot \mathrm{min}^{-1}$, and sampling depth $-8 \mathrm{~mm}$. All of the analytical standard stock solutions were TraceCert (Sigma-Aldrich) for ICP $\left(100 \mathrm{mg} \cdot \mathrm{l}^{-1}\right)$. The limit of detection (LoD) for the determined elements was $0.02 \mu \mathrm{g} \cdot \mathrm{l}^{-1}$, and the limit of quantification (LoQ) was $0.06 \mu \mathrm{g} \cdot 1^{-1}$. The linear range for the measurements by the ICPMS method was up to $10 \mathrm{mg} \cdot \mathrm{l}^{-1}$. The relative standard deviation (RSD) for analysis of one sample replicate did not exceed $6 \%$. For the calibration graph standard, solutions in the concentration range from 0.1 to $50.0 \mu \mathrm{g} \cdot \mathrm{l}^{-1}$ were used. Calibration solutions were prepared from stock standard solutions. A calibration graph with blank correction was used for calculating the concentrations of elements in the samples. An Internal Standard Mix solution from Agilent Technologies (10 $\mathrm{mg} \cdot \mathrm{ml}^{-1}$ ) was used as an internal standard. A stability check of the ICP-MS system was performed by using two standard solutions after every ten samples. For the quality control of the analytical procedures, the same elements were also determined for certified reference material (CRM) BCR-060-Aquatic plant (Lagarosiphon major) supplied by the IRMM (Geel, Belgium). The CRM was analysed at the beginning and at the end of each analytical sequence. The differences between certified and measured values did not exceed $10 \%$. Two replicates of each sample were used for analysis. A MassHunter workstation software together with its Instrument control and Offline data analysis programmes was used.

For the determination of $\mathrm{N}$ and $\mathrm{C}$, the samples were weighed into tin capsules (the weight of each sample was $\sim 1 \mathrm{mg}$ ) and then analysed in duplicate on an EA3000 elemental analyser (EuroVector) coupled to a Nu-horizon continuous flow mass spectrometer (Nu Instruments). A quality 
control standard sample of glutamic acid was used to check the reproducibility of measurements. Reference material USGS-40 ()(L-glutamic acid, Restek, Virginia, USA)) was used to control accuracy of the method.

Analysis of variance (ANOVA) was used to identify significant differences in element concentration between samples from different plots. The $\mathrm{F}$ value was used as a criterion for the significance of differences, where differences were considered significant if $\mathrm{F}>$ Fcrit at $95 \%$ confidence level $(p \leq$ $0.05)$.

\section{RESULTS}

The concentrations of elements in faba beans are summarised in Table 1.

The obtained results showed that the most significant differences in element concentration occurred in the leaves of faba beans. After treatment of legume with rhizobia, there were noticeable changes of $\mathrm{Na}, \mathrm{Mg}, \mathrm{P}, \mathrm{K}, \mathrm{Ca}, \mathrm{Zn}$, and $\mathrm{N}$ concentration. Also there were observable increases of $\mathrm{Na}$ and $\mathrm{Mg}$ concentrations in faba seeds. The concentrations of $\mathrm{P}$ and $\mathrm{K}$ decreased in faba seeds.

The concentrations of elements in soybean are summarised in Table 2.

Significant increase of $\mathrm{Mg}, \mathrm{K}, \mathrm{Ca}, \mathrm{Fe}, \mathrm{Cu}, \mathrm{Zn}$, and $\mathrm{N}$ levels in soya leaves was observed after treatment with rhizobia. There was also an increase of $\mathrm{N}$ concentration in seeds and an increase of $\mathrm{Cu}$ in soya stems. Decrease of element concentration occurred for $\mathrm{Mn}$ in soya leaves, and $\mathrm{Na}, \mathrm{Mg}, \mathrm{P}$, $\mathrm{K}, \mathrm{Ca}, \mathrm{Fe}, \mathrm{Cu}$ in soya seeds. The concentrations of $\mathrm{Mg}, \mathrm{P}$, $\mathrm{K}, \mathrm{Ca}, \mathrm{Mn}, \mathrm{Fe}$, and $\mathrm{N}$ decreased in soya stems.

The results of experiments showed that the concentrations of different mineral elements in faba bean leaves increased differently. The largest increase was observed in concentrations of the macronutrients $\mathrm{Na}$ and $\mathrm{K}$, an increase of $38.8 \%$ and $16.2 \%$, respectively. Both elements are osmotically ac-

Table 1. Element concentrations in faba beans

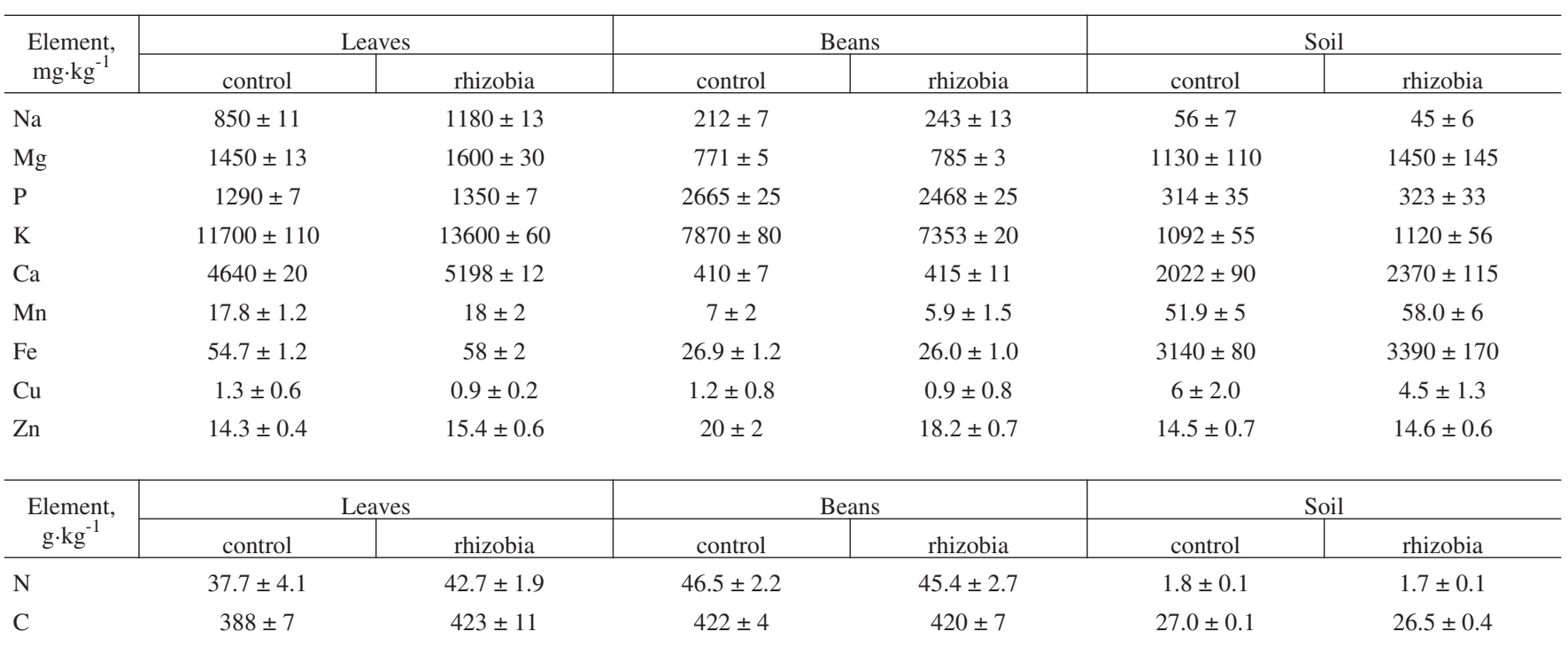

Table 2. Element concentrations in soybeans

\begin{tabular}{|c|c|c|c|c|c|c|c|c|}
\hline \multirow{2}{*}{$\begin{array}{l}\text { Element, } \\
\mathrm{mg} \cdot \mathrm{kg}^{-1}\end{array}$} & \multicolumn{2}{|c|}{ Leaves } & \multicolumn{2}{|c|}{ Beans } & \multicolumn{2}{|c|}{ Stem } & \multicolumn{2}{|c|}{ Soil } \\
\hline & control & rhizobia & control & rhizobia & control & rhizobia & control & rhizobia \\
\hline $\mathrm{Na}$ & $15.3 \pm 0.8$ & $14.3 \pm 0.5$ & $6.6 \pm 0.6$ & $4.6 \pm 0.7$ & $19.1 \pm 1.2$ & $17.2 \pm 1.9$ & $54 \pm 5$ & $56 \pm 6$ \\
\hline $\mathrm{Mg}$ & $2975 \pm 16$ & $3220 \pm 17$ & $1390 \pm 11$ & $1290 \pm 9$ & $3040 \pm 20$ & $2690 \pm 14$ & $2090 \pm 100$ & $2140 \pm 105$ \\
\hline $\mathrm{P}$ & $1455 \pm 13$ & $1470 \pm 18$ & $4740 \pm 9$ & $4120 \pm 40$ & $962 \pm 8$ & $922 \pm 13$ & $192 \pm 9$ & $190 \pm 10$ \\
\hline $\mathrm{K}$ & $7980 \pm 40$ & $8525 \pm 70$ & $11400 \pm 130$ & $10600 \pm 140$ & $9910 \pm 90$ & $9290 \pm 70$ & $2040 \pm 100$ & $2170 \pm 110$ \\
\hline $\mathrm{Mn}$ & $24.0 \pm 1.1$ & $18.7 \pm 0.8$ & $8.0 \pm 0.3$ & $8.4 \pm 0.6$ & $10.0 \pm 0.8$ & $5.0 \pm 0.4$ & $108 \pm 11$ & $165 \pm 16$ \\
\hline $\mathrm{Fe}$ & $289.6 \pm 0.9$ & $303.9 \pm 0.4$ & $47.6 \pm 1.1$ & $41.6 \pm 1.5$ & $147.5 \pm 0.7$ & $104.0 \pm 0.7$ & $7200 \pm 720$ & $8920 \pm 890$ \\
\hline $\mathrm{Cu}$ & $1.2 \pm 0.2$ & $2.5 \pm 0.3$ & $7.2 \pm 0.2$ & $5.8 \pm 0.6$ & $0.6 \pm 0.2$ & $1.4 \pm 0.7$ & $3.6 \pm 0.9$ & $3.5 \pm 0.6$ \\
\hline $\mathrm{Zn}$ & $11.0 \pm 1.2$ & $13.2 \pm 0.7$ & $24.9 \pm 1.1$ & $23.6 \pm 1.4$ & $5.8 \pm 0.5$ & $6.0 \pm 0.8$ & $18.6 \pm 0.9$ & $18.3 \pm 0.4$ \\
\hline $\begin{array}{c}\text { Element, } \\
\mathrm{g} \cdot \mathrm{kg}^{-1}\end{array}$ & \multicolumn{2}{|c|}{ Leaves } & \multicolumn{2}{|c|}{ Beans } & \multicolumn{2}{|c|}{ Soil } & \multicolumn{2}{|c|}{ Leaves } \\
\hline $\mathrm{N}$ & $31.4 \pm 0.5$ & $32.9 \pm 0.3$ & $47.0 \pm 1.3$ & $54.3 \pm 1.3$ & $14.4 \pm 0.2$ & $13.4 \pm 0.3$ & $1.0 \pm 0.1$ & $1.1 \pm 0.1$ \\
\hline $\mathrm{C}$ & $447 \pm 1$ & $432 \pm 5$ & $511 \pm 8$ & $512 \pm 4$ & $435 \pm 2$ & $432 \pm 6$ & $12.5 \pm 1.8$ & $14.0 \pm 0.3$ \\
\hline
\end{tabular}


tive, and thus can change plant water regimes and the intensity of physiological processes. The $\mathrm{Mg}$ concentration of bean leaves increased by $10.3 \%$, which in turn may promote plant photosynthetic activity as it is incorporated in chlorophyll. Ca concentration increased by $12 \%$.

The largest differences between inoculated and noninoculated plants were found in $\mathrm{Cu}$ concentration in faba bean leaves, but as the concentration of this micro-element in the plant was low, these differences were not significant. A significant increase (7.7\%) was observed in $\mathrm{Zn}$ concentration.

The results showed an increase of $\mathrm{Na}$ and $\mathrm{Mg}$ concentrations in faba bean seeds by $38.8 \%$ and $10.3 \%$, respectively, and a decrease of $\mathrm{P}$ and $\mathrm{K}$ concentration by $7.4 \%$ and $6.6 \%$, respectively.

As in faba beans, an increase in the concentration of macronutrients in the leaves of soya plants was observed: Ca by $21.9 \%, \mathrm{Mg}$ by $8.2 \%$, and $\mathrm{K}$ by $6.8 \%$. The level of the micro-element $\mathrm{Zn}$ also increased, by $20 \%$. In contrast to faba beans, $\mathrm{Cu}$ concentration increased twice in soya leaves. Soybeans had a significant reduction in macronutrients and $\mathrm{Fe}$ and $\mathrm{Cu}$ concentration as a result of inoculation. A significant reduction of mineral nutrients was also detected in soya stems.

In most cases, the concentrations of mineral elements in parts of both plants were similar. However, faba bean leaves had 55-83 times higher sodium concentration. This was also observed in seeds.

\section{DISCUSSION}

Nitrogen. Nitrogen is an essential element occurring in urea, proteins (amino acids), nucleic acids (DNA and RNA), adenosine triphosphate (ATP), nicotinamide adenine dinucleotide (NAD), and chlorophyll. Nitrogen fixation occurs primarily in root nodules. Ironically, in the presence of high mineral $\mathrm{N}$ concentration in the soil, nodule formation and activity of nitrogenase is inhibited. Studies show that there is a clear negative effect on nodule formation and $\mathrm{N}$ fixation in soybeans at very high $\mathrm{N}$ concentrations (Buren and Rubio, 2017; Lindström and Mousavi, 2020). In experiment fields, the initial concentration of $\mathrm{N}$ in soil was low and in the range from 1 to $1.8 \mathrm{~g} \cdot \mathrm{kg}^{-1}$. After treatment with rhizobia, elevated $\mathrm{N}$ concentration in leaves (from 38 to 43 $\mathrm{g} \cdot \mathrm{kg}^{-1}$ faba beans and from $31 \mathrm{~g} \cdot \mathrm{kg}^{-1}$ to $33 \mathrm{~g} \cdot \mathrm{kg}^{-1}$ in soybeans) was observed. Also, the concentration of $\mathrm{N}$ increased from 47 to $54 \mathrm{~g} \cdot \mathrm{kg}^{-1}$ in soybean seeds, which was a clear indicator for effective $\mathrm{N}$ fixation. A significant increase in nitrogen concentration due to the influence of $R h i$ zobium was also reported by Francini et al. (2010), where, depending on the variety of garden beans, an increase in nitrogen concentration by $48.8-68.1 \%$ was observed. The results obtained by Uyanöz et al. (2012) showed that inoculation of garden beans with rhizobia increased the nitrogen concentration in dry garden bean seeds by $0-5 \%$.
Phosphorus. $\mathrm{P}$ is involved in most plant physiological processes, particularly energy acquisition, utilisation, and storage. A decrease in supply of $\mathrm{P}$ leads to limited symbiosis and ineffective nitrogen fixation (Vardien et al. 2014). It was reported (Míguez-Montero et al., 2020) that nitrogenfixing plants have greater demand for $\mathrm{P}$, probably due to the formation of nodules, which can explain the observed decrease of $\mathrm{P}$ concentration in seeds of faba beans and soybeans (from 2670 to $2470 \mathrm{mg} \cdot \mathrm{kg}^{-1}$ faba beans and from 4740 to $4120 \mathrm{mg} \cdot \mathrm{kg}^{-1}$ in soybeans) and in the stem of soybeans (from 960 to $920 \mathrm{mg} \cdot \mathrm{kg}^{-1}$ ). Other studies showed that the effect of inoculation on phosphorus concentration in plant shoots depended even on the variety of garden beans used (Francini et al., 2010), and caused a slight increase of $\mathrm{P}$ concentration (on average by $10.8 \%$ ) in dry seeds (Uyanöz et al., 2012).

Potassium. $\mathrm{K}$ is a very mobile element, and it acts as a signal transductor in major cationic cellular osmotic systems. It activates more than 60 enzyme systems, but $\mathrm{K}$ is not included in the structure of these enzymes. The high mobility of $\mathrm{K}$ ensures that it can be translocated from older to younger leaves. That is the reason why old leaves show the first symptoms of $\mathrm{K}$ deficiency. Also, some rhizobia require a minimal amount of $\mathrm{K}$ for efficient nodule development (Hasanuzzaman et al., 2018). The formation of nodules, as well as formation of leaves, maybe the main reason why in legumes treated with rhizobia, $\mathrm{K}$ has lower concentration in seeds (from 7900 to $7400 \mathrm{mg} \cdot \mathrm{kg}^{-1}$ faba beans and from 11 $400 \mathrm{mg} \cdot \mathrm{kg}^{-1}$ to $10600 \mathrm{mg} \cdot \mathrm{kg}^{-1}$ in soybeans) and higher concentration in new actively forming leaves (from 11700 to $13600 \mathrm{mg} \cdot \mathrm{kg}^{-1}$ faba beans and from $7980 \mathrm{mg} \cdot \mathrm{kg}^{-1}$ to 8525 $\mathrm{mg} \cdot \mathrm{kg}^{-1}$ in soybeans). Data on $\mathrm{K}$ concentration in garden beans due to inoculation are contradictory. For some garden bean varieties, inoculation promoted potassium accumulation in shoots, but a significant increase in potassium concentration in the seeds has been observed (Francini et al., 2010; Uyanöz et al., 2012).

Calcium. $\mathrm{Ca}$ is one of the main macronutrients in plants. $\mathrm{Ca}$ ions have low mobility and are actively excluded from plant cytoplasm. Ca also has a great role in buffering the negative effect of mineral soils with low $\mathrm{pH}$ value on nodule formation. Higher soil $\mathrm{pH}$ value has a positive effect on nodule formation. There has been reported that $\mathrm{Ca}$ deficiency also lowers the nitrogen fixation rate in plant nodules (RedondoNieto et al., 2003). No effect on calcium concentration in the shoots of garden beans was observed, but increased levels in seeds on average by $10 \%$ as a result of inoculation was detected (Francini et al., 2010; Uyanöz et al., 2012). The obtained results showed that there was an increase in Ca concentration in leaves (from 4640 to $5200 \mathrm{mg} \cdot \mathrm{kg}^{-1} \mathrm{faba}$ beans and from $6300 \mathrm{mg} \cdot \mathrm{kg}^{-1}$ to $7700 \mathrm{mg} \cdot \mathrm{kg}^{-1}$ in soybeans). There was also there is a decrease in Ca concentration in soybean leaves and seeds (from 655 to $560 \mathrm{mg} \cdot \mathrm{kg}^{-1}$ seeds and from $4970 \mathrm{mg} \cdot \mathrm{kg}^{-1}$ to $4330 \mathrm{mg} \cdot \mathrm{kg}^{-1}$ in the stem), which was probably due to redistribution of $\mathrm{Ca}$ in the infection process. 
Copper. $\mathrm{Cu}$ is included in respiratory proteins that are required for nitrogen fixation and affect the efficiency of bacteroid function. Despite $\mathrm{Cu}$ being one of the microelements that is incorporated within some enzymes like tyrosinase, higher amounts of $\mathrm{Cu}$ lead to toxic effects for nodule formation (Tindwa et al., 2014). The obtained results showed no significant changes in $\mathrm{Cu}$ concentration in faba beans, but there was increased concentration in soybean leaves and stems (from 1.2 to $2.5 \mathrm{mg} \cdot \mathrm{kg}^{-1}$ seeds and $0.6 \mathrm{mg} \cdot \mathrm{kg}^{-1}$ to 1.4 $\mathrm{mg} \cdot \mathrm{kg}^{-1}$ in the stem) and decreased concentration in soybean seeds (from 7.2 to $5.8 \mathrm{mg} \cdot \mathrm{kg}^{-1}$ seeds). Other experiments show that despite the increased copper uptake in inoculated alfalfa plants by $45.6 \%$ (the concentration of copper sulphate used was $400 \mathrm{mg} \cdot \mathrm{kg}^{-1}$ ), inoculation reduced the negative effect of the increased copper dose on both the length and mass of the alfalfa (Jian et al., 2019). Synergistic effect of $\mathrm{Zn}$ and $\mathrm{Cu}$ was reported, and the effect depended on the used dose of $\mathrm{Zn}$. No additional $\mathrm{Zn}$ or a small dose decreased $\mathrm{Cu}$ concentration in garden bean seeds, but a higher dose of zinc together with inoculation with rhizobia increased $\mathrm{Cu}$ concentration by $35.2 \%$ (Uyanöz et al., 2012).

Zinc. In small amounts, $\mathrm{Zn}$ is needed for all crop plants. Zn application decreases the negative effect of salinity stress (Zhang et al., 2020). This study showed a small increase of $\mathrm{Zn}$ concentration in leaves of faba and soybeans (from 14 to $15 \mathrm{mg} \cdot \mathrm{kg}^{-1}$ in faba bean leaves and from 11 to $13 \mathrm{mg} \cdot \mathrm{kg}^{-1}$ in soybean leaves). An increase of zinc concentration on average by $15 \%$ as a result of inoculation with rhizobia was observed in dry garden bean seeds (Uyanöz et al., 2012). An increase in $\mathrm{Zn}$ concentration by $13.1 \%$ in alfalfa shoots as a result of inoculation has been reported (Jian et al., 2019).

Iron. Fe plays a very important role in nodule formation. It is required in many enzymes like nitrogenase, ferredoxin, and some hydrogenases. Fe is needed in oxygen-binding protein of plants - Leghaemoglobin. Nitrogenase and nitrogenase reductase contains FeS clusters for the reduction of molecular nitrogen. There were no significant changes in Fe concentration in faba beans. However, there was increased $\mathrm{Fe}$ concentration in soybean leaves (from 290 to $304 \mathrm{mg} \cdot \mathrm{kg}^{-1}$ ) and decreased Fe concentration in soybean seeds and stems (from 48 to $42 \mathrm{mg} \cdot \mathrm{kg}^{-1}$ in seeds and from $147 \mathrm{mg} \cdot \mathrm{kg}^{-1}$ to $104 \mathrm{mg} \cdot \mathrm{kg}^{-1}$ in the stem). Other studies showed that inoculation promoted the accumulation of iron in garden beans on average by $11.3 \%$ (Uyanöz et al., 2012).

Manganese. Mn is involved in the synthesis of polyamines, which are very important for plant growth and development. There was no observable Mn change in faba beans, but there was a decrease of Mn concentration in soybean leaves and stems (from 24 to $19 \mathrm{mg} \cdot \mathrm{kg}^{-1}$ in leaves and from 10.0 to $5.0 \mathrm{mg} \cdot \mathrm{kg}^{-1}$ ). Therefore, with a decrease of $\mathrm{Mn}$ in seeds and stem there was a noticeable increase in soil (an increase from 52 to $58 \mathrm{mg} \cdot \mathrm{kg}^{-1}$ in soil from faba beans and an increase from 110 to $165 \mathrm{mg} \cdot \mathrm{kg}^{-1}$ in soybean soil). Mn uptake by plants depends on the manganese concentration in the soil, soil and air temperature, soil moisture, and other factors (Mederski et al., 1958). Synergistic effects of Zn on Mn uptake have been observed. Inoculation with rhizobia stimulated the accumulation of $\mathrm{Mn}$ in garden bean seeds (Uyanöz et al., 2012).

\section{CONCLUSIONS}

The obtained results showed that inoculation of legume plants with rhizobia not only altered nitrogen uptake by plants but also caused differences in the concentration of other elements. Inoculants have a greater effect on mineral elements on both faba bean and soybean leaves, causing significant increase in $\mathrm{Mg}, \mathrm{P}, \mathrm{K}$, and $\mathrm{Ca}$ concentrations. Treatment of legume plants with rhizobia causes a decrease of $\mathrm{P}$ and $\mathrm{K}$ in seeds, and also changes in Fe and Mn concentrations. Inoculation with rhizobia caused an increase of $\mathrm{Na}$ and $\mathrm{K}$ concentrations by $38.8 \%$ and $16.2 \%$, respectively, in actively growing parts.

No significant differences in mineral element concentration were observed between tested legumes, except for Na concentration, which was 55-83 times higher in faba bean leaves than in soybeans. This was also observed for seeds of these plants.

The obtained results show that pre-sowing inoculation of legume seeds with rhizobia can significantly increase the concentration of mineral elements in faba and soya bean leaves, which can affect the photosynthetic activity of these plants and result in yield increase. The mineral concentration of the beans in the inoculated variants did not in most cases significantly differ from the control, or there was a decrease in mineral element inoculation with rhizobia, which can be explained by an increase in the organic matter content (including protein) in seeds.

Use of rhizobia strains diminishes the need for use of nitrogen fertiliser, but the gained increase in plant organic matter and decrease in some element concentrations ( $\mathrm{P}$ and $\mathrm{K}$ ) indicates the need to use additional mineral element fertilisers to maintain wholesome nutrient-rich food products. The results of this study can help to develop better cultivation conditions in terms of mineral element concentration in soil for growing legumes with maximum possible yield and nutritional value of obtained products.

\section{REFERENCES}

Brear, E. M., Day, D. A., Smith, P. M. (2013). Iron: an essential micronutrient for the legume-rhizobium symbiosis. Frontiers Plant Sci., 4, 359.

Burén, S., Rubio, L. M. (2018). State of the art in eukaryotic nitrogenase engineering. FEMS Microbiol. Lett., 365 (2), fnx274.

Chojnacka, K., Moustakas, K., Witek-Krowiak, A. (2020). Bio-based fertilizers: A practical approach towards circular economy. Biores. Technol., 295, 122223

Dubova, L., Alsiņa, I., Ruža, A., Šenberga, A. (2018). Impact of faba bean (Vicia faba L.) cultivation on soil microbiological activity. Agron. Res., 16 (5), 2016-2025.

Francini, V. I., Azcon, R., Mendes, F. L., Aroca, R. (2010). Interactions between Glomus species and Rhizobium strains affect the nutritional physiology of drought stressed legume hosts. J. Plant Physiol., 167, 614-619. 
Hasanuzzaman, M., Bhuyan, M. H. M. B., Nahar, K., Hossain, M. S., Mahmud, J. A., Hossen, M. S., Masud, A. A. C., Moumita, M., Fujita, M. (2018). Potassium: A vital regulator of plant responses and tolerance to abiotic stresses. Agronomy, 8 (3), 31.

Jian, L., Bai, X., Zhang, H., Song, X., Li, Z. (2019). Promotion of growth and metal accumulation of alfalfa by coinoculation with Sinorhizobium and Agrobacterium under copper and zinc stress. Peer J., 7, e6875.

Lindström, K., Mousavi, S. A. (2020). Effectiveness of nitrogen fixation in rhizobia. Microbial Biotechnol., 13 (5), 1314-1335.

Maphosa, Y., Jideani V.A. (2017). The role of legumes in human nutrition. In: Hueda, M. C. (Ed.). Functional Food: Improve Health through Adequate Food. doi:10.5772/intechopen.69127.

https://www.intechopen.com/chapters/55808 (accessed 26.10.2021).

Mederski, H. J., Hoff, D. J. (1958). Manganese deficiency in soybeans. In: Ohio Agricultural Experiment Station. Trace elements. Proceedings of the Conference. Academic Press, New York, 381, Oh32, pp. 99-108.

Messina, M. J. (2016). Legumes and soybeans: Overview of their nutritional profiles and healtheffects. Asia Pacific J. Clin. Nutr., 25 (1), 1-17.

Míguez-Montero, M. A., Valentine, A., Pérez-Fernández, M. A. (2020). Regulatory effect of phosphorus and nitrogen on nodulation and plant performance of leguminous shrubs, AoB Plants, 12 (1), plz047.

Minta, M., Tsige, A. (2014). Effect on Rhizobium inoculation on herbage yield, quality, and nitrogen fixation of annual forage legumes on nitisols in central highlands of Ethiopia. Acta Adv. Agricult. Sci., 2 (10), 29-48.

Mitran, T., Meena, R. S., Lal, R., Layek, J., Kumar, S., Datta, R. (2018). Role of soil phosphorus on legume production. In: Meena, R., Das, A., Yadav, G., Lal, R. (eds.). Legumes for Soil Health and Sustainable Management. Springer, Singapore, pp. 487-510.

Mogobe, O., Mosepele, K., Masa, W. R. L. (2015). Essential mineral content of common fish speciesin Chanoga, Okavango Delta, Botswana. Afr. J. Food Sci., 9 (9), 480-486.
Poole, P., Ramachandran, V., Terpolilli, J. (2018). Rhizobia: From saprophytes to endosymbionts. Nature Rev. Microbiol., 16 (5), 291-303.

Redondo-Nieto, M., Wilmot, A. R., El-Hamdaou, A., Bonilla, I., Bolanos, L. (2003). Relationship between boron and calcium in the $\mathrm{N}_{2}$-fixing legume rhizobia symbiosis. Plant Cell Environ., 26, 1905-1915.

Šenberga, A., Dubova, L., Alsiņa, I., Strauta, L. (2017). Rhizobium sp. — a potential tool for improving protein content in peas and faba beans. Rural Sustain. Res., 37 (332), 2-9.

Tena, W., Wolde-Meskel, E., Walley, F. (2016). Symbiotic efficiency of native and exotic rhizobium strains nodulating lentil (Lens culinaris Medik.) in soils of southern Ethiopia. Agronomy, 6 (1), 11.

Tindwa, H., Semu, E., Msumali, G. P. (2014). Effects of elevated copper levels on biological nitrogen fixation and occurrence of rhizobia in a Tanzanian coffee-cropped soil. J. Agricult. Sci. Appl., 3 (1), 13-19.

Uyanöz, R., Karaca, Ü., Özaytekin, H. (2012). The effect of rhizobium inoculation and the application of zinc on micro and macro nutrient uptake in dry bean (Phaseolus vulgaris L.). Int. J. Ecosyst. Ecol. Sci. (IJEES), 2 (3), 201-208.

Vardien, W., Mesjasz-Przybylowicz, J., Przybylowicz, W. J.,Wang Y., Steenkamp, E. T., Valentine, A. J. (2014). Nodules from Fynbos legume Virgilia divaricata have high functional plasticity under variable $\mathrm{P}$ supply levels. J. Plant Physiol., 171, 1732-1739.

Weisany, W., Raei, Y., Allahverdipoor, K. H., Ecology, A. (2013). Role of some of mineral nutrients in biological nitrogen fixation. Bull. Env. Pharmacol. Life Sci., 2 (4), 77-84

Zhang P., Zhang B., Jiao J., Dai S-Q., Chen W-X., Tian C-F. (2020). Modulation of symbiotic compatibility by rhizobial zinc starvation machinery. mBio 11 (1), e03193-19.

\section{GUMIN̦BAKTĒRIJU IETEKMES PĒTĪJUMI UZ MINERĀLELEMENTU SATURU TAURIṆZIEŽU DZIMTAS AUGOS}

Zemes atmosfērā ir aptuveni 78\% slāpekḷa, taču lielākā daḷa augu nespēj to tieši uzṇemt no atmosfēras. Visizplatītākais veids atmosfēras slāpekḷa saistīšanai ir efektīvas simbiotiskās sistēmas izveide starp pākšaugiem un gumiņbaktērijām. Šì pētījuma mērḳis bija salīdzināt, kā dažādu pākšaugu un gumiṇbaktēriju simbiozes sistēmu izmantošana ietekmē minerālelementu saturu pupās un sojas pupiṇās. Lauka pupu un sojas sēklas tika inokulētas ar gumiṇbaktēriju preparātiem tieši pirms sēšanas. Augu veǵetatīvās daḷas analīzēm tika ievāktas ziedēšanas fāzes laikā, bet sēklas pēc nogatavošanās. Paraugus žāvēja gaisā un analizēja ar induktīvi saistītās plazmas masas spektrometrijas metodi (ICP-MS). Kopējais slāpekḷa un oglekḷa saturs tika noteikts ar elementu analizatoru (EA). No iegūtajiem rezultātiem var secināt, ka tauriṇziežu sēklu inokulācija ar gumiņbaktērijām ietekmē minerālelementu akumulāciju augu veǵetatīvajās daḷās un sēklās. Tiek novērota palielināta slāpekḷa uzņemšana, kā arī izmaiņas citu elementu saturā. Pākšaugu apstrāde ar gumiṇbaktērijām izraisa P samazināšanos sēklās, kā arī izmaiṇas dzelzs un mangāna sastāvā. 